\title{
Inside "Chinese Democracy": The Official Career of a Contested Concept under Xi Jinping
}

\author{
Heike Holbig ${ }^{1}$ \\ ${ }^{1}$ Faculty of Social Sciences, Goethe University, Frankfurt/Main, Germany \\ Correspondence: Heike Holbig, Faculty of Social Sciences, Goethe University, Campus Westend, PEG Postbox \\ 17, Frankfurt/Main, Germany. E-mail: holbig@soz.uni-frankfurt.de
}

Received: March 27, 2021

doi:10.5539/jpl.v15n2p21

\author{
Accepted: February 16, $2022 \quad$ Online Published: March 4, 2022 \\ URL: https://doi.org/10.5539/jpl.v15n2p21
}

\begin{abstract}
When the People's Republic of China was excluded from US president Biden's guest list for the virtual Summit for Democracy in December 2021, it reacted with a detailed self-depiction of the Chinese political system as a "Democracy That Works" to rebut US claims to be the world's leading democracy. While the international media saw this as a surprise narrative, China's "democratic" self-image has a long trajectory going back to the days of Mao Zedong and now elaborated more systematically under Xi Jinping. Based on a close reading of Chinese partystate documents, white papers, state media coverage, etc., this article analyzes the official career of the concept of "democracy" in Chinese Communist Party jargon and dissects the messages targeted at domestic and international audiences. It finds that the official self-depiction of "Chinese democracy" does not contradict, but rather complements the legitimation of Communist Party rule at home, buffering nationalist sentiments there. Despite its lack of persuasiveness vis-à-vis Western audiences, its underlying criticism of US democracy, and its subtle claims regarding China's global leadership, the official vision might gain traction among other emerging powers and developing countries.
\end{abstract}

Keywords: People's Republic of China, Chinese Communist Party, Xi Jinping, democracy, party ideology, propaganda

\section{Introduction}

When US president Joseph Biden launched his virtual Summit for Democracy in December 2021, the People's Republic of China (PRC) was not among the more than one hundred invited guests. As the international media knew, the whole event had been designed to exclude China (and Russia, for that matter) and to rally old and new allies to support the USA in its emerging great-power rivalry with China. The message was also brought home to the PRC leadership by the fact that various other unequivocal autocracies such as Angola, the Democratic Republic of Congo and Iraq were among the invited parties, as were India and Brazil, two backsliding democracies led by staunch populists. In the case of Singapore's hybrid regime, which was not invited, US diplomats made it clear that this was not a judgment "on our partnership" (Sim 2021).

The message of strategic exclusion was not lost on China's party-state leaders. Instead of snubbing their noses and tacitly ignoring the event, the party regime reacted in a conspicuously vocal manner that came as a surprise to many. Five days before the summit, the State Council Information Office, one of the external arms of the party's propaganda apparatus, published a white paper on "Chinese democracy" (Zhongguo de minzhu), with the title translated into English as "China: Democracy That Works" (SCIO 2022). The white paper outlined an institutionally well-established, pragmatic, and effective mode of governance that was practiced everyday across China. According to the authors, "Chinese democracy" has not only won the support of Chinese citizens but also serves as a "new model of democracy" for others to emulate - and one that is superior to US democracy.

As this article demonstrates, the PRC's official self-image as a "democracy that works" has not emerged overnight. Rather, narratives of a Chinese-style "democracy" have evolved in the party language since the founding of the PRC and particularly since late 2012, when Xi Jinping took over as paramount leader of the Chinese party-state. This stands in stark contrast to the fact that the Chinese Communist Party (CCP) regime is widely viewed as the antithesis of liberal democracy as defined by open, free, and fair elections. Democracy in China thus appears to most outside observers as an oxymoron. 
Against this backdrop, the objective of this article is to analyze China's self-perceptions and worldviews as a major global power, not to normatively evaluate Chinese democracy or euphemize official attempts at political selflegitimation. It employs a context-sensitive approach in order to explore processes of experimentation with, adaptation of, localization of, and reinterpretation of the notion of democracy. In other words, when official Chinese narratives about "democracy" are quoted or paraphrased in the following, it is not to propagate them but to offer a better sense of the changing tonalities in party discourse and of the internal logics of justification.

The article proceeds as follows. To set the scene, it outlines Western perceptions of China's political system that have been articulated in recent years. Against this backdrop of outside images, it then delves into the official selfimages of Chinese democracy as propagated by the CCP. While developments over the first six decades of the PRC are outlined only roughly, a more detailed analysis of the period since late 2012, when Xi Jinping took power as China's paramount leader, is provided. Five exemplary cases of the use of democracy in party language have been selected, in chronological order, to illustrate the changes in official visions of the notion of democracy under Xi Jinping. The conclusion offers some reflections on the importance of understanding Chinese visions of democracy "from inside" and the potential implications they might have for the international realm.

Before proceeding, a few words on the data and methods used are in order. To understand the self-image of "Chinese democracy," the article offers a textual analysis of official documents provided by CCP organs and the propaganda apparatus that deal with the concept of "democracy" in the context of the Chinese party-state. They include important speeches by party-state leaders, resolutions and other documents emanating from party meetings and other official events, state media coverage, and propaganda material such as white papers, wall posters, or video clips. Some of the materials are available only in Chinese language; however, whenever official English translations have been provided, as is the case for party congress resolutions or white papers, they are analyzed in tandem. In fact, as this article hopes to illustrate, comparing the messages sent to domestic and to external audiences helps pinpoint the party-state leadership's rationale in telling the story of "Chinese democracy." Overall, the underlying assumption is that official discourse and the linguistic intricacies of party language should not be dismissed as "empty talk" but should rather be taken seriously for what they are meant to be: attempts to legitimize $\mathrm{CCP}$ rule at home and abroad. The extent to which these attempts are successful or not is, of course, another matter. But making sense of the self-perceptions and worldviews of China's party-state leadership, and being aware of their visions, narratives and self-portrayals, appears to be the unavoidable first step.

\section{Western Perceptions of China's Political System}

Western political science is unequivocal about China's political system being a textbook example of an autocracy. ${ }^{1}$ This is true for democracy indices such as Polity IV, Freedom in the World, the Democracy Index of the Economist Intelligence Unit, or the Varieties of Democracy (V-Dem) Index. All of them have consistently ranked post-Mao China as an "autocracy," "not free," an "authoritarian regime," or a "closed autocracy," respectively. In 2016, Francis Fukuyama - author of the 1989 essay "The End of History" - pondered that "China is a real test case. It is the only alternative to a liberal, capitalist democracy. The country is technologically and economically advancedbut it pursues modernization without democracy" (Die Zeit 2016, author's translation).

From the perspective of political practitioners in the West, China is not only an autocracy, but also one that is increasingly and proactively challenging liberal democracies. Back in 2007, a German member of parliament described China's combination of a "modern authoritarian" political system with a "capitalist" economic system as one of the biggest strategic challenges for Europe (Von Klaeden 2007, author's translation). Twelve years later, in March 2019, the European Union labeled China "a systemic rival promoting alternative models of governance" in its watershed "Strategic Outlook" on EU-China relations (European Commission 2019).

In the United States, shortly before the 2020 elections, Robert O'Brien, Trump's national security adviser, argued in a Foreign Affairs article, "For decades, conventional wisdom in the United States held that it was only a matter of time before China would become more liberal, first economically and then politically. We could not have been more wrong - a miscalculation that stands as the greatest failure of U.S. foreign policy since the 1930s [...]. Today, [...] the CCP's ideological agenda extends far beyond the country's borders and represents a threat to the idea of democracy itself' (O'Brien 2020).

In the same magazine, as part of his own electoral campaign, Joseph Biden called China "a special challenge [...]. China is playing the long game by extending its global reach, [and] promoting its own political model." To meet that challenge, he called for a "united front of U.S. allies and partners," and even then envisaged holding a Summit

\footnotetext{
${ }^{1}$ Parts of the manuscript are based on a keynote lecture held by the author at the symposium "China's Belt and Road Initiative: Curse or Blessing for democracy in Eurasia?" (organized by OSCE Academy and DVPW), Bishkek, March 12-13, 2021 (digital conference).
} 
for Democracy "to renew the spirit and shared purpose of the nations of the free world" (Biden 2020). And throughout 2021, China was indeed high on President Biden's agenda. As we can see from these examples - and many others that could be added - China is not merely seen as one non-democratic regime among others. Rather, it has increasingly been pitted against the liberal democracies of the West and as the number one challenge to "the idea of democracy itself' (O'Brien 2020).

\section{Official Self-Portrayals of China's Political System before Xi Jinping}

In China, the concept of democracy has been used for some time to refer to the Chinese body politic. The term "democracy" (minzhu) itself has not been considered an alien concept since the founding of the CCP a century ago. As part of the vocabulary of Europe's "long 19th century," the term was adopted into the Chinese language via Japanese around 1900. Under the social-Darwinist worldview of the time, it denoted the quintessential modern, civilized, and sovereign nation-state, with all the prerequisites to prevail as a body politic in the quest for the survival of the fittest (Amelung and Holbig 2016). "Democracy" also had a positive connotation in Mao Zedong's historical treatises on "new democracy" in the 1940s as the signifier of his strategy to co-opt social elites who fought for national emancipation alongside the CCP.

The "People's Republic of China," founded in October 1949, was based on the Leninist principle of "democratic centralism" (minzhu jizhongzhi), a concept that is still alive and well today (e.g., White Paper 2021). According to this principle, leaders are formally elected and key policies discussed collectively, but as the vanguard of the revolution, the party leadership has the final say and the political decisions reached through these voting processes are binding for all members of the party. The country's first constitution of 1954, modeled on the Soviet Union, established the National People's Congress as the embodiment of popular sovereignty under the leadership of the CCP. The most recent constitution of 1982, which reacted to the Maoist excesses of the Cultural Revolution, reconfirmed the principle of democratic centralism and the formal status of the National People's Congress as the highest organ of state power (Holbig and Schucher 2016).

The ideas of Chinese democracy in the reform era launched by Deng Xiaoping in 1978 were spelled out most authoritatively in a 2005 white paper. This document defined the main features of "socialist political democracy." Most important among them was that "China's democracy is a people's democracy under the leadership of the Communist Party of China," and that "China's democracy is a democracy in which the overwhelming majority of the people act as masters of state affairs [...]" (SCIO 2005). The notion of "people's democracy" (renmin minzhu), in particular, appears as a pleonasm to Western ears. In socialist jargon, it denotes the alternative to Western democracies based on multiparty systems, which are considered to be dominated by capitalist elites. The idea that the people act as "masters of the state" combines the party's legitimizing claim of people's sovereignty with the principle of party leadership, which is regarded as a prerequisite to ensure the people's role as masters of the state. As the 2005 white paper further elaborated, China exhibits multiple elements of a democracy, including the following:

- The system of People's Congresses that formally elect state leaders (though only among preselected candidates)

- The system of Chinese People's Political Consultative Conferences as symbols of the party's United Front (which comprise co-opted social and economic elites)

- Experience with grassroots democracy in villages and urban resident committee elections (which are manipulated by the party)

- Economic and political rights for citizens and respect for human rights (which was codified in the constitution in 2004 but is interpreted in a parochial manner)

Last but not least, the 2005 white paper emphasizes that the party promotes so-called inner-party democracy (dangnei minzhu). This includes experiments with inner-party elections, where party organizations and members can nominate candidates, and where the ratio of excess candidates has been raised over time to make these innerparty elections more competitive (SCIO 2005).

To summarize, the 2005 white paper illustrates that the Chinese party-state strove to position itself as an institutionally fully-fledged and successful democratic system long before Xi Jinping's ascent to become the country's paramount leader. However, the claim that the Chinese party regime is a democracy has been articulated much more assertively under Xi Jinping's leadership — and, from the beginning, with a view to rivaling US claims of embodying the idea of democracy itself. 


\section{Official Visions of Democracy under Xi Jinping}

During the final years of the Hu-Wen era, domestic and international voices had openly criticized the political stalemate and stagnation, which they blamed on the weak collective leadership style cultivated by Hu Jintao. Many hoped for a new bold vision and authority at the top, and for a strongman leader to get things done. Indeed, this is what they got. In October 2012, just a few weeks before the 18th Party Congress that would baptize Xi Jinping as the new secretary-general of the party, Chinese television disseminated an animated video titled "How Leaders Are Made," which went viral among Chinese and foreign audiences ("How Leaders are Made" 2012).

The five-minute clip compares how leaders rise to power in the USA and in China. The US process-featuring a smiling Barack Obama - is caricatured as a series of drawn-out and costly election campaigns, political stringpulling, and the overriding importance of the final act of voting. In contrast, the Chinese process is depicted as selecting the president—-featuring a smiling Xi Jinping —on the basis of merit and skills. Candidates earn these skills over the course of long political careers, moving up the administrative ladder and facing various acid tests. The clip concludes,

Many roads lead to national leadership, and every country has one for itself. Whether by a single ballot that gets the whole nation out to vote or by meritocratic screening that requires years of hard work like the making of a kung fu master, as long as people are satisfied and the country develops and progresses as a result, it's working. ("How Leaders Are Made" 2012)

Although the term "democracy" is not used in the clip, the film invokes central elements thereof, such as public interest and popular consent. In this Chinese version of democracy, merit replaces campaigning, candidates are screened instead of elected, and performance output tops procedural input and accountability. The following five exemplary visions show how these and other previous narratives of Chinese "democracy" have evolved during the first two terms of Xi Jinping's leadership, from November 2012 to the present day.

\subsection{Consultative Democracy}

To start with, only a subtle shift of emphasis in the official discourse on China's "democracy with adjectives" could be observed between the lines of the report of the 18th Party Congress in November 2012. On the one hand, the notion of "inner-party democracy," which had been promoted by Xi's predecessor Hu Jintao (cf. SCIO 2005), was now downplayed. Instead, the 2012 document stressed the importance of so-called "consultative democracy." As I have outlined elsewhere, this concept had been imported and adapted in party theory circles for more than a decade. To make a long story short, "consultative democracy" (xieshang minzhu) was imported as a localized version of Jürgen Habermas's notion of "deliberative democracy" (xieshang minzhu), which Habermas himself had introduced to Chinese university students during a visit to Beijing in 2001 (Holbig 2016). His idea of openended public communication among free and equal citizens, who confer and take decisions based on the "unforced force" of rational argument, has gained much currency among Chinese academics since then. In the course of its official Chinese adaptation, however, Habermas's original idea of horizontally structured deliberation between citizens has been reinterpreted in the Chinese context as a vertical pattern of consultation organized top-down by the party center, as illustrated by the following passage from the report of the 18th Party Congress:

Socialist consultative democracy is an important form of people's democracy in our country. [...] Extensive consultations should be carried out on major issues relating to economic and social development as well as specific problems involving the people's immediate interests [...] to solicit a wide range of opinions, pool wisdom of the people, increase consensus, and build up synergy. We should adhere to and improve the system of $[\ldots]$ political consultation under the leadership of the Communist Party of China. (CPC Central Committee 2012: section 2)

Five years later, in his report to the CCP's 19th Party Congress in October 2017, Xi Jinping rephrased this idea even more succinctly: "The essence of the people's democracy is that the people get to discuss their own affairs. Consultative democracy is an important way of effecting Party leadership and a model and strength unique to China's socialist democracy" (CPC Central Committee 2017: section 1). Thus, according to the official Chinese notion of consultative democracy, the people, represented by selected members of important social and ethnic groups, are consulted in a hierarchical fashion by the party-state to forge a consensus and thereby legitimize party rule, and the consultation process is circumscribed by the CCP's organizational and ideological monopoly on leadership. In other words, Xi Jinping has not only reduced the extent of inner-party competition and collective leadership promoted by Hu Jintao, but he also appears to be more inclined than his predecessor to keep "democratic consultation" within proper limits and to open this exercise up only to those segments of society that the party can control (Cabestan 2019). 


\subsection{Democracy as a "Socialist Core Value"}

Yet democracy is not always accompanied by adjectives in the official Chinese discourse under Xi Jinping. Soon after his installation as the country's new paramount leader, the propaganda apparatus presented a set of twelve "socialist core values" (shehuizhuyi hexin jiazhi), with "democracy"-without adjectives-as one of them.

According to the report of the 18th Party Congress, the socialist core values "are the soul of the Chinese nation and serve as the guide for building socialism with Chinese characteristics" (CPC Central Committee 2012). Praised as "the common denominator for the values of socialism" (Qiushi, 2012: 12) and nicely portrayed visually in myriad wall posters across the country, the twelve core values are laid out on three different levels: the nationstate, society, and the individual level, with four values ascribed to each level. At the nation-state level, "prosperity" and "democracy" come first, followed by "civility" and "harmony." These four values are seen as national objectives and as having a guiding role over all other values. The four core values at the level of society are "freedom," "equality," "justice," and "rule of law," and at the personal level, "patriotism," "dedication," "integrity," and "friendliness." Within this hierarchical set of values, it is important to note that "democracy" is positioned at the level not of society but of the nation-state, thereby signaling a quality ascribed to the nation as a whole, not to procedures or structures within the state. In the authoritative text published for the official inauguration of the socialist core values campaign in May 2013, the term was defined along the lines of the 2005 white paper, but extended to include the vision of "a beautiful and happy life" for the people:

Democracy is a beautiful aspiration of human society. The democracy we strive for is a people's democracy, and its true core is the people acting as masters of the state. Democracy is the life of socialism, and the political guarantee for creating a beautiful and happy life for the people. (People's Daily 2013; author's translation)

The socialist core values campaign continues today. In a recent study, Miao (2021) analyzed a collection of almost 400 propaganda posters that have been disseminated online and offline across the country since 2013, coming to a very interesting finding: While the twelve core values have been replicated as a complete set over time, only six of them have been illustrated in detail in the propaganda posters - namely, "prosperity, civility and harmony as national-level values, and patriotism, friendliness, and integrity as personal-level values" (Miao 2021). "Democracy," as well as "freedom," "equality," "justice," and "rule of law," are often absent from the themespecific posters. As the author argues, these missing values

$[\ldots]$ have very specific [...] definitions, all of which fall under the strict guideline of the party-state. As individuals are not expected to interpret or contribute towards these values, but instead are considered the beneficiaries in a society where these values will be allowed to prosper, values such as democracy and rule of law are not popularised in the poster collection. (Miao 2021: 169)

Despite this toning-down of "democracy" relative to some other core values, its ubiquitous presence on rural walls, urban subway billboards and online might have a two-pronged effect. On the one hand, propaganda inculcates the notion of "democracy" without adjectives in peoples' minds and everyday language. On the other hand, the very notion of democracy is tamed and immunized against potential challengers who might strive to interpret democracy in more specifically procedural ways than the official idea of a "beautiful aspiration of human society" (People's Daily 2013).

\subsection{China as the "World's Largest Democracy"}

Given this domesticated version of democracy, it might not come as a surprise that official Chinese media have hailed the country as the "world's largest democracy." In August 2015, the party-controlled Global Times (Huanqiu Shibao) ran this headline: "Which Is Ultimately the Largest Democratic Nation?" (Han 2015). The answer is obvious, but it is important to see how the argument is constructed.

The article starts with an attack on the West, above all the USA, which, in the author's view, has tried for a long time to exclude China from the global values discourse for being "undemocratic." In contrast, India — which, at the time was still the "world's largest democracy" in the eyes of the West-is found to enjoy an unjustifiably high level of trust from the West due to the same normative bias. Against this backdrop, the article then argues that it is time for China to break free from the "discourse trap" and secure the prerogative of interpreting global values as well as the essence of democracy. "Democracy" is described as a historically formed term that has developed differently in various epochs and regions and for which there are no fixed standards. The Arab Spring and its aftermath are mentioned to show that the Western democratic model is not compatible with non-Western cultural contexts. The lesson to be learned is that without stability and order, neither prosperity for the people nor civilizational progress will be achieved. 
The article then claims that China represents a particularly "genuine" and "effective" form of democracy compared to others. In contrast to many façade democracies across the globe, the author argues, China ensures that different social strata are adequately represented in the political process. Unlike the case in "certain states," the Chinese people do not merely have the choice between different "political dynasties" on election day. Instead, they are involved on a daily basis in a number of important decision-making processes through a range of consultative mechanisms. Overall, the article concludes, socialism with Chinese characteristics has been proven to represent the true interests of the people, and the country's economic success proves the vitality of the democratic system; thus China can be considered the "largest democratic nation." The author ends on a moralistic tone: last but not least, the article pleads, it is time for China to make this clear and no longer silently accept its-falseundemocratic image (Han 2015).

What we find here is a new dimension in China's official vision of democracy, if not a new habitus on the part of the Chinese leadership. Whether or not these claims appear plausible is apparently less relevant than the underlying claims challenging Western democracies: the call to end Western discourse hegemony, the call to project China's own discourse power and contest Western interpretations of global values, and the claim that China actually outperforms its Western counterparts in various regards (Holbig and Schucher 2016).

\subsection{Democracy in the "New Era"}

The role of democracy in the "New Era" inaugurated by Xi Jinping at the 19th Party Congress in October 2017 entails the definition of a new "principal contradiction" in China's society. According to the Marxist strand of historical materialism, each period of social development is characterized by a specific principal contradiction, and its correct identification allows the vanguard party to solve it and thereby further the socialist cause.

In line with this logic, the Mao era was characterized by the contradiction between the "proletariat and the bourgeoisie," which had to be solved by class struggle. In the early reform era under Deng Xiaoping, the principal contradiction was "between the ever-growing material and cultural needs of the people versus backward social production" (Xinhua 2017). According to Xi Jinping, this contradiction has been solved in the meantime thanks to China's unparalleled economic performance and the improvement of peoples' livelihoods over the past four decades. Thus, in the "New Era," the principal contradiction is no longer about quantity but quality. It is now a contradiction "between unbalanced and inadequate development and the people's ever-growing needs for a better life" (CPC Central Committee 2017), and this is where democracy comes in. The "better life" which people demand, in Xi's words, includes "democracy, rule of law, fairness and justice, security, and a better environment" (CPC Central Committee 2017). Indeed, "democracy" appears here as the first among various aspirational values that are propagated as expressions of a "better life"- and as a vision among other visions that the party promises to realize with a view to satisfying the people.

Putting his vision in historical perspective, Xi Jinping envisages the middle of the twenty-first century as the time when China will have developed into a "rich and strong, democratic, civilized, harmonious and beautiful modernized socialist strong nation" (CPC ${ }^{2}$ Central Committee 2017, literal translation of fuqiang minzhu wenming hexie meili de shehuizhuyi xiandaihua qiangguo). In the official English translation provided by Xinhua News Agency, the same phrase is rendered as a "great modern socialist country that is prosperous, strong, democratic, culturally advanced, harmonious, and beautiful" (CPC Central Committee 2017), thereby avoiding the repetition of "strong" vis-à-vis international audiences. In the Chinese original, however, the term "strong" (qiang) is used twice-Xi Jinping's innovative contribution to the CCP's strategic target for 2049, when the PRC will celebrate its centennial.

As we can learn from these slogans, democracy is part and parcel of the official party-state vision for China, not only in the present but also, and even more so, in the future. At the same time, the claim of a democratic China is bracketed by the call to become a strong nation and a great power by the middle of the century. What we see here might be the reemergence of a vocabulary that was characteristic of the Social Darwinist worldview of the late nineteenth century, of a struggle between nations, where being "democratic" appears to be an evolutionary advantage in the survival of the fittest in the international realm (cf. Amelung and Holbig 2016).

\footnotetext{
${ }^{2}$ While this article uses the conventional American-English acronym CCP (Chinese Communist Party), official English translations provided by the Chinese propaganda apparatus consistently use CPC (Communist Party of China).
} 


\section{5 "Democracy That Works"}

As the introduction mentions, the white paper on "Chinese Democracy" was drafted in anticipation of the virtual Summit for Democracy launched by President Biden on December 9-10, 2021, from which the PRC was conspicuously excluded. The publication date coincided with China's National Constitution Day, celebrated on December 4 each year, a fact ignored in the English-language media coverage but not lost on popular Chineselanguage online media (e.g., Tencent Net 2021). ${ }^{3}$

On the one hand, the 12,000-character Chinese text represents a continuation of and update to the previous narratives, concepts, and institutional practices related to Chinese "democracy" elaborated above. On the other hand, it introduces various new propositions, slogans, and institutional practices that are described as highly innovative (featured in eleven "special columns" interspersed throughout the text). Taken together, previous and more recent components are rearranged to form a new narrative and a "new model of democracy" (English version) intended by the CCP to "enrich humanity's political civilization" (fengfu renlei zhengzhi wenming, author's translation).

Beginning with the familiar components of this "new model of democracy," the white paper reminds its readers of the historic mission of the CCP, which from its early days "led the people in their tenacious fight for democracy." It repeatedly mentions concepts and slogans coined in the Mao era, among them the "mass line" (qunzhong luxian), "the people's status as masters of the country" (renmin dangjia zuozhu), and "people's democratic dictatorship" (renmin minzhu zhuanzheng). It describes the institutional organisation of the country's "socialist democracy" (shehuizhuyi minzhu) highlighted previously in the 2005 white paper (People's Congresses, multiparty cooperation and political consultation, the broad patriotic united front, and the systems of regional autonomy and of community-level self-governance, but not "inner-party democracy"; see SCIO 2005 and the discussion above). As a tribute to the "New Era" inaugurated by Xi Jinping in 2017, the recent white paper expounds on the new principal contradiction characterizing current Chinese society: the need "to meet the people's expectation for a better life" (shixian renmin dui meihao shenghuo xiangwang), including their aspirations towards democracy.

This familiar set of "democratic" institutions and practices, however, is now inscribed into a new framework labeled "whole-process people's democracy" (quan guocheng renmin minzhu). As we can see from its definition, the new concept claims to present a holistic entity that includes all the prerequisites of modern democracies but recalibrates them to form a "true democracy" superior to previously existing versions due to its extraordinary effectiveness:

Whole-process people's democracy integrates process-oriented democracy with results-oriented democracy, procedural democracy with substantive democracy, direct democracy with indirect democracy, and people's democracy with the will of the state. It is a model of socialist democracy that covers all aspects of the democratic process and all sectors of society. It is a true democracy that works. (SCIO 2021: 2)

Peppered with side blows at US election campaigns, the white paper's main message is centered around claims about what really counts in democracies. It argues that the right to participate in political affairs is more important than the right to vote, that the continuous merits of "consultative democracy" trump the one-time merits of "electoral democracy," and that the fulfillment of promises after elections is more important than verbal promises given during election campaigns. The document also states,

[w] hether a country is democratic depends on [...] whether there are set political procedures and rules in state systems and laws, and more importantly, whether these systems and laws are truly enforced; whether the rules and procedures for the exercise of power are democratic, and more importantly, whether the exercise of power is genuinely subject to public scrutiny and checks. (SCIO 2021:3)

While most readers would readily agree with these statements in principle, they must all be read as being subject to CCP leadership. According to the internal logic of the white paper's line of argument, the merits of "wholeprocess people's democracy" hinge fully on party rule. The party knows best what the people aspire to and what they need; the party allows the people to vote and to participate; the party provides, interprets, and enforces relevant rules and procedures; and the party decides when, where, and to whom to apply public scrutiny. According to the same logic, China's "whole-process people's democracy" is claimed to be created and orchestrated by the party for the sake of the people, while at the same time securing the maintenance of party rule:

Whole-process people's democracy is a creation of the CPC in leading the people to pursue, develop and realize democracy, embodying the Party's innovation in advancing China's democratic theories, systems

\footnotetext{
${ }^{3}$ If not indicated otherwise, the verbatim quotes in this section are taken from the English version of the 2021 white paper.
} 
and practices. The Party's history of struggle is a course of rallying the people and leading them to explore, establish and develop whole-process people's democracy. It is a logical outcome of history, theory and practice based on the strenuous efforts of the people under the leadership of the Party. It is a requisite for maintaining the very nature of the Party and fulfilling its fundamental purpose. (SCIO 2021: 7)

In this teleological sense, the seeming pleonasm of "people's democracy" corresponds with the party's leadership underlying the "whole process." According to this interpretation, it is thanks to the party that the people know what to aspire to, and the fulfillment of these aspirations can be achieved only through the fulfillment of the party's fundamental purpose.

To bring home the message of the superiority of "Chinese democracy" to its intended audience, the white paper ponders that "[i]t is hard to see how a country can serve as a good example for the rest of the world if its own model of democracy is unsuccessful or inefficient in national governance" (SCIO 2021: 41). The downsides ascribed to Western democracies are "social rifts and conflicts, $[\ldots]$ chaos and turmoil, $[\ldots]$ instigating negativity and promoting the false and the evil" (SCIO 2021: 45). In contrast, democracy in China is claimed to

unit[e] the Party, the government and the people behind shares goals, interests and aspirations. This generates a huge cohesive force that translates into one of China's great institutional strengths - the ability to pool resources to accomplish major initiatives (chansheng jida de ouheli, xingcheng jizhong liliang ban dashi) [...]. (SCIO 2021: 41)

Clearly, this passage points to the Achilles heel of democratic systems' performance worldwide. As the corona pandemic, which is mentioned a few times in the white paper, has demonstrated, democracies can have a hard time uniting their citizens and formulating effective response strategies to tackle crises. The argument is bolstered by the dramatic failure of US president Trump's corona politics, and it appears compelling as long as the underlying trade-off between security and freedom, and between lives and living, is ignored. On top of this, however, the white paper presents an even stronger provocation to the present US leadership by denying its qualification to "serve as an example for the rest of the world" (SCIO 2021: 41) and to rally other countries around the flag of its-flawed, as the white paper argues between the lines-democracy.

Instead, the PRC argues for its right to provide "a new model of democracy" (SCIO 2021: 1, English version only), which is claimed not only to serve the Chinese people best, but also to contribute to the best of "humanity" (renlei). What might appear as a lofty goal in the name of humankind can also be read as a public relations effort to delegitimize US claims to represent democracies worldwide and to legitimize China's own claims on global leadership.

Whole-process people's democracy carries distinctive Chinese characteristics on the one hand, while exemplifying the common values of the entire humanity (quan renlei gongtong jiazhi), and it contributes China's wisdom and China's plan to enrich and develop the political civilization of humanity (wei fengfu he fazhan renlei zhengzhi wenming gongxian le Zhongguo zhihui, Zhongguo fang'an). (SCIO 2021: 7) ${ }^{4}$

Most interestingly, while the term renlei (humanity, (hu)mankind) is mentioned 36 times in the Chinese version of the white paper, it is translated accordingly only twelve times in the English version. Obviously, the CCP's lofty ambition of making a contribution to human civilization is perceived by the authors and translators of the white paper to be more relevant for the legitimation of party rule — and maybe more persuasive — vis-à-vis domestic audiences than international ones (cf. Holbig 2021).

Overall, the 2021 white paper thus sends a two-fold message: first, and most explicitly, the self-legitimation of "Chinese democracy" under CCP rule for the sake of the global good; and second, between the lines, a stark criticism of US democracy and of its claim to represent democracies worldwide. In fact, the latter message was spelled out in another bilingual publication in the Global Times (Huanqiu Shibao), one of the more outspoken party organs with a traditionally nationalist voice.

Two days after the white paper's appearance and three days before President Biden's virtual launch of the Summit for Democracy, the newspaper published an extensive essay titled "10 Questions for American Democracy" (Global Times 2021). It featured a caricature of a crumbling Greek-style temple of "US DEMOCRACY," the roof of which was stabilized only by a jittering president with a "SUMMIT FOR DEMOCRACY" sign around his neckthe obvious pun being that the only purpose of the international summit was to stabilize a defunct US democracy at home. In its many answers to the questions raised, with a rhetoric designed to turn the tables on US criticisms

\footnotetext{
${ }^{4}$ This is the author's translation of the Chinese original, as the official English translation is missing part of the civilizational rhetoric. The corresponding passage of the white paper's English version is: "Whole-process people's democracy has distinctive Chinese characteristics; it also exemplifies common values and contributes China's ideas and solutions to the political progress of humanity" (SCIO 2021: 7).
} 
of China, the author(s) argued that US democracy privileges a minority, invites abuse of power due to a lack of effective checks and balances, deepens people's suffering and reduces their well-being, hinders personal freedom, and violates human rights. Besides endemic gun violence and racial discrimination, the authors pointed to the "massacre" of risking the death of over 800,000 Covid-19 victims (Global Times 2021: Sect. 5.3) The article went on to insinuate that US democracy has increased social rifts and division, performed poorly not only with regard to disaster management but also in a more general socioeconomic sense, and has brought disillusion and despair to younger generations instead of allowing them to realize the "American dream." From a global perspective, it accused US democracy of bringing about disaster and turmoil, producing multiple refugee crises, undermining world peace, and using military and financial means to project its "[h]egemony, arrogance and bullying" (Global Times 2021: Sect. 10.3).

The Global Times article thus covered both the domestic and the international level, in the same way as the white paper, though with a much more aggressive rhetorical style. By upending the conventional perspectives on human rights violations, geopolitical revisionism, and hegemony, the essay signaled a strong indignation about China's exclusion from the international Summit for Democracy. At the same time, it appeared to pick up the gauntlet and rally the Chinese nation and its old and new allies to counter what is perceived as US hegemony. It is hard to say whether this was meant as a tactical move to avert the insult of exclusion or a strategic reversal to take up the geopolitical rivalry with the USA in a material and normative sense. Even if the attack was of a tactical nature for a limited time only, its rallying call might not have gone unheard and may result in more aggressive forms of nationalism. In other words, this could be a form of "propaganda that works." While explicitly targeting US democracy, the implicit message projected domestically translates into a call to arms to rebut what is perceived as the continuation of humiliations and insult.

\section{Implications for China's International Interactions}

To conclude, I offer some reflections on what the official Chinese visions of democracy might imply for China's interactions with other world regions and countries.

Firstly and generally, this article has illustrated the importance of taking into account the self-perceptions and worldviews of actors in different regions and their changing roles in international power constellations. This approach also allows for a better assessment of Chinese expectations, ideological positions, strategic portfolios, and preferences, not only vis-à-vis domestic audiences but also vis-à-vis foreign countries and actors.

Secondly, China's official visions of democracy can be seen as an almost ironic response to the widespread perceptions that China challenges, not only regarding Western liberal democracies but also regarding the idea of democracy itself. Whether or not these visions are plausible and credible appears to be less important than the contestation of what is perceived as the long-standing (discourse) hegemony of the USA and the West at large.

Thirdly, China's alternative narratives on democracy might gain traction in the context of newly emerging geopolitical alliances. Bolstered by its own economic clout, China's rejection of the perceived US hegemony could make a growing impression on actors in other world regions. Against the backdrop of the declining global appeal of Western-type liberal democracies since the rise of populist leaders in the USA, Europe, and other world regions, we cannot rule out the possibility that a growing number of actors in developing countries and emerging economies increasingly perceive China as an alternative international rule-maker.

Last but not least, much will depend upon the self-image of Western democracies. The varying effectiveness of public health responses to the Covid-19 pandemic in countries worldwide has shaken, if not severely damaged, the liberal democracies' self-confidence regarding their superior capacity to deliver public goods. It is hard to tell whether China's robust response to the pandemic at home and its vaccine diplomacy abroad will lend more credence to its official visions of democracy. However, the malaise of Western liberal democracies - which has worsened in the wake of the pandemic - is buttressing China's attempts to contest the perceived discourse hegemony of the West and to project its own interpretations of global values such as democracy and other "beautiful aspirations of human society."

\section{References}

Amelung, I., \& Holbig, H. (2016). Introduction: Protecting the Weak. Welfare during East Asia's Long Twentieth Century. Critical Asian Studies, 48(3), 309-314. https://doi.org/10.1080/14672715.2016.1200307

Biden, J. R. Jr. (2020, March/April). Why America Must Lead Again. Rescuing U.S. Foreign Policy After Trump. Foreign Affairs.

Cabestan, J.-P. (2019). The Contradictions of Xi Jinping's Socialist Democracy. In J. G. Bowie (Ed.), Party Watch Annual Report 2019. Scrambling to Achieve a Moderately Prosperous Society (pp. 24-34). Washington DC: 
Center for Advanced China Research.

Communist Party of China (CPC) Central Committee. (2012). Firmly March on the Path of Socialism with Chinese Characteristics and Strive to Complete the Building of a Moderately Prosperous Society in All Respects (Jianding bu yi yanzhe Zhongguo tese shehuizhuyi daolu qianjin, wei quanmian jiancheng xiaokang shehui er fendou). Full text of Hu Jintao's Report to the 18th Party Congress, delivered on 27 Nov 2012. Official English translation. Retrieved October 2, 2021, from http://www.chinaembassy.org/eng/zt/18th_CPC_National_Congress_Eng/t992917.htm

Communist Party of China (CPC) Central Committee. (2017). Secure a Decisive Victory in Building a Moderately Prosperous Society in All Respects and Strive for the Great Success of Socialism with Chinese Characteristics for a New Era (Juesheng quanmian jiancheng xiaokang shehui duoqu xin shidai Zhongguo tese shehuizhuyi weida shengli). Full text of Xi Jinping's Report to the 19th Party Congress, delivered on 18 October 2017. Official English translation. Retrieved October 3, 2021, from http://www.xinhuanet.com/english/download/Xi_Jinping\%27s_report_at_19th_CPC_National_Congress.pd $\mathrm{f}$

DIE ZEIT. (2016, March 17). Die Demokratie stiftet keine Identität. Ist das Modell des Westens am Ende? Ein Gespräch mit dem amerikanischen Politikwissenschaftler Francis Fukuyama. Interview with Francis Fukuyama in the German weekly magazine, no. 13. Retrieved October 2, 2021, from https://www.zeit.de/zustimmung?url=https\%3A\%2F\%2Fwww.zeit.de $\% 2$ F $2016 \% 2$ F $13 \% 2$ Ffrancisfukuyama-politikwissenschaftler-populismus-usa

European Commission and High Representative of the Union for Foreign Affairs and Security Policy. (2019, March 12). EU - China A Strategic Outlook. Joint Communication to the European Parliament, the European Council and the Council. Retrieved December 15, 2021, from https://ec.europa.eu/info/sites/default/files/communication-eu-china-a-strategic-outlook.pdf

Global Times (Huanqiu Shibao). (2021, December 6). 10 Questions for American Democracy. Retrieved January 6, 2022, from https:/www.globaltimes.cn/page/202112/1240755.shtml

Han, Z. (2015, August 27). Which is the largest democratic nation after all? (Jiujing shei shi zuidade minzhu?), Global Times (Huanqiu Shibao). Retrieved August 28, 2021, from http://opinion.huanqiu.com/opinion_world/2015-08/7361939.html

Holbig, H., \& Schucher, G. (2016). „He who says C must say D“. China’s Attempt to Become the „World's Largest Democracy“ (Wer C sagt, muss auch D sagen: Chinas Anlauf zur „,weltgrößten Demokratie“). GIGA Focus Asia, (2). Retrieved January 4, 2022, from https://pure.gigahamburg.de/ws/files/24348647/gf_asien_1602_english.pdf

Holbig, H. (2016). Demokratie als translinguale Praxis: Chinesische Aneignungen "deliberativer Demokratie". In S. Schubert, \& A. Weiß (Eds.), Demokratie"jenseits des Westens: Theorien, Diskurse, Einstellungen, Sonderheft 51, Politische Vierteljahreschrift (PVS) (pp. 188-205). Baden-Baden: Nomos. https://doi.org/10.5771/9783845261904-189

Holbig, H. (2021, July). Hundert Jahre Einsamkeit. Die KP Chinas probt ihren globalen Führungsanspruch (One Hundred Years of Solitude: The CCP tests its claim to global leadership). GIGA Focus Asia, (4), 1-12. Retrieved January 14, 2022, from https:/www.giga-hamburg.de/de/publikationen/giga-focus/hundert-jahreeinsamkeit-die-chinas-probt-ihren-globalen-fuehrungsanspruch

"How Leaders are made" (Lingdaoren shi zenyang liancheng de). (2012, October 15). Video clip released by “On the Road to Rejuvenation” Producers Collective (Fuxing lu shang gongzuoshe). Retrieved October 2, 2021, from https://www.youtube.com/watch?v=M734o_17H_A

Miao, Y. (2021). Romanticising the Past: Core Socialist Values and the China Dream as Legitimisation Strategy. Journal of Current Chinese Affairs, 49(2), 162-184. https://doi.org/10.1177/1868102620981963

O'Brien, R. C. (2020, September/October), How China Threatens American Democracy. Beijing's Ideological Agenda Has Gone Global. Foreign Affairs.

People's Daily (Renmin Ribao). (2013, May 22). Socialist Core Values (Shehuizhuyi hexin jiazhiguan). Retrieved February 4, 2021, from http://theory.people.com.cn/n/2013/0522/c40531-21565926.html

Seeking Truth (Qiushi). (2012, January). Research Report on Core Socialist Values (Shehuizhuyi xin jiazhiguan yanjiu baogao). Qiushi, 24(2), 12-26. 
Sim, D. (2021, December 02). Singapore's non-invite to Biden's democracy summit "not a judgment": US diplomat Daniel Kritenbrink. South China Morning Post. Retrieved January 5, 2022, from https://www.scmp.com/week-asia/politics/article/3158195/singapores-non-invite-bidens-democracysummit-not-judgment-us

State Council Information Office (SCIO). (2005, October). White Paper: Building of Political Democracy in China. Beijing: SCIO Publishing House. Retrieved September 27, 2021, from http://www.china.org.cn/english/2005/Oct/145718.htm

State Council Information Office SCIO. (2021, December 4). White Paper: China: Democracy That Works (Zhongguo de minzhu). Beijing: SCIO Publishing House. Full English text. Retrieved January 5, 2022, from http://www.news.cn/english/2021-12/04/c_1310351231.htm. Full bilingual Chinese-English edition available at http://language.chinadaily.com.cn/a/202112/07/WS61aefdb1a310cdd39bc79e03.html

Tencent Net (Tengxun Wang). (2021, December 4). Heavyweight White Paper on "Chinese Democracy" Published on Today's National Constitution Day (Guojia xianfari zhetian, "Zhongguo minzhu” baipishu zhongbang fabu) Retrieved January 5, 2022, from https://new.qq.com/omn/20211204/20211204A04HBJ00.html

Von Klaeden, E. (2007, October 23). Asien als strategische Herausforderung und Chance für Deutschland und Europa. Asienstrategie der CDU-CSU-Bundestagsfraktion. Retrieved September 27, 2021, from www.cducsu.de/sites/default/files/asienstrategie_web.pdf

Xinhua News Agency. (2017, October 20). Grasping the new characteristics of the principal social contradiction in depth (Shenke bawo shehuizhuyi zhuyao maodun bianhua de xin tedian). Retrieved September 15, 2021, from http://news.xinhuanet.com/2017-10/20/c_1121833637.htm

\section{Copyrights}

Copyright for this article is retained by the author(s), with first publication rights granted to the journal.

This is an open-access article distributed under the terms and conditions of the Creative Commons Attribution license (http://creativecommons.org/licenses/by/4.0/). 